\title{
Evaluasi Pembelajaran Nilai-Nilai Aneka dan Pengaruhnya Terhadap Perilaku Alumni Latsar CPNS
}

\author{
Burdan Ali Junjunan \\ Lembaga Administrasi Negara \\ Correspondence email: H.burdanalijunjunan@gmail.com
}

\begin{abstract}
Abstrak. Aparatur Sipil Negara (ASN) harus mampu mengaktualisasikan lima nilai dasar ASN yang terdiri dari Akuntabilitas, Nasionalisme, Etika Publik, Komitmen Mutu, dan Anti Korupsi (ANEKA) berdasarkan Undang-Undang Nomor 5 Tahun 2014 Tentang ASN. Nilai-nilai dasar ANEKA ini merupakan modal awal ASN dalam menjalankan tugas pokok dan fungsinya di institusi kerjanya. Penelitian ini bertujuan untuk mengetahui pengaruh pemahaman nilai-nilai dasar ANEKA terhadap perubahan perilaku sebelum dan sesudah pelatihan dasar (Latsar) CPNS. Penelitian ini menggunakan mixed methods research. Pada tahapan kuantitatif, data dari 162 orang peserta Latsar CPNS Angkatan 1 sampai 12 Tahun 2019 yang dikumpulkan melalui survei kuesioner dianalisis menggunakan teknik metode Paired Samples $t$ Test, sedangkan tahapan kualitatif dengan melakukan proses wawancara dan kuesioner terbuka kepada 162 orang peserta Latsar CPNS Angkatan 1 sampai 12 Tahun 2019 dan 8 orang pejabat unit kerja para peserta latsar dianalisis secara deskriptif. Hasil penelitian menunjukkan bahwa terdapat pengaruh nilai-nilai dasar Akuntabilitas (X1), Nasionalisme (X2), Etika Publik (X3), Komitmen Mutu (X4) dan Anti Korupsi (X5) saat sebelum dan sesudah mengikuti Latsar CPNS terhadap perubahan perilaku pada peserta Latsar CPNS, sehingga menurut pejabat unit kerjanya terjadi perubahan perilaku para peserta secara signifikan sesuai dengan perilaku yang diharapkan sebagai seorang CPNS yang profesional dibandingkan dengan sebelum diikutsertakan pada Latsar CPNS serta terdapat hambatan yang dialami oleh para peserta Latsar CPNS yaitu mendapatkan kesulitan untuk mengaktualisasikan nilai-nilai dasar ANEKA dalam bentuk perilaku kerja
\end{abstract}

Kata Kunci: Pelatihan Dasar; ANEKA; ASN; Perilaku.

Abstract. The State Civil Apparatus (ASN) must be able to actualize the five basic values of ASN which consist of Accountability, Nationalism, Public Ethics, Quality Commitment and Anti-Corruption (ANEKA) based on Law Number 5 of 2014 concerning ASN. These basic values of ANEKA are the initial capital for ASN in carrying out its main duties and functions in the working institution. This study aims to determine the effect of understanding the basic values of ANEKA on behaviour change before and after basic training (Latsar) CPNS. This research uses mixed methods research. In the quantitative stage, data from 162 CPNS Class 1 to 12 the Year 2019 Latsar participants collected through a questionnaire survey were analyzed using the Paired Samples $t$-Test method technique, while the qualitative stage was conducted by conducting an interview process and open questionnaires to 162 CPNS Class 1 to 12 of 2019 and 8 supervisors of the work unit of the Latsar participants were analyzed descriptively. The results showed that there was an effect of the basic values of Accountability (X1), Nationalism (X2), Public Ethics (X3), Quality Commitment (X4) and Anti-Corruption (X5) in before and after attending CPNS Latsar on behaviour changes in Latsar participants. CPNS so that according to the supervisor of the work unit there was a significant change in the behaviour of the participants by the expected behaviour as a professional CPNS compared to before being included in the CPNS Latsar and there were obstacles experienced by the CPNS Latsar participants having difficulty actualizing ANEKA's basic values in the form of work behaviour.

Keyword: Basic Training; ANEKA; ASN; Behaviour

\section{PENDAHULUAN.}

Hampir semua negara telah melakukan reformasi birokrasi, karena memang banyak elemen negara termasuk masyarakat merasa belum puas dengan kinerja pemerintah yang tidak menyejahterakan masyarakatnya (Riccucci, Naff, \& Hamidullah, 2019). Reformasi manajemen sipil menjadi bagian dari reformasi birokrasi untuk meningkatkan pemerintahan menjadi arah yang lebih baik (Mutia Ali, Prasojo, \& Jannah, 2017), Pegawai negeri adalah salah satu target rencana dari reformasi, pembuat kebijakan dan pelaksana kebijakan, baik atau buruk kebijakan tersebut implementasinya tergantung dari pengguna atau pegawai negeri yang mengimplementasikannya. Dalam posisi tersebut, Aparatur Sipil Negara (ASN) memiliki posisi penting untuk menciptakan tata kelola yang baik atau buruk (Grindle, 2007). Di Indonesia, dalam rangka melaksanakan cita-cita dan mewujudkan tata kelola terkait ASN, Pemerintah mengeluarkan Undang-Undang Nomor 5 Tahun 2014 Tentang Aparatur Sipil Negara. Peraturan tersebut mengamanatkan perlu dibangunnya ASN yang memiliki integritas, profesional, netral dan bebas dari intervensi politik, bersih dari praktik korupsi, kolusi dan nepotisme (KKN), serta mampu menyelenggarakan pelayanan publik bagi masyarakat. ASN memiliki fungsi sebagai: 1) pelaksana kebijakan publik, 2) pelayan publik dan 3) perekat dan pemersatu bangsa. Guna melaksanakan fungsi tersebut, maka memiliki tugas 1) melaksanakan kebijakan publik yang dibuat oleh pejabat pembina kepegawaian sesuai dengan 
ketentuan peraturan perundang-undangan, 2) memberikan pelayanan publik yang profesional dan berkualitas serta 3) Mempererat persatuan dan kesatuan negara kesatuan republik Indonesia (Pemerintah Republik Indonesia, 2014).

Dalam rangka mewujudkan PNS yang mampu melaksanakan tugas dan mengemban fungsi tersebut, PNS harus di didik dan di latih agar memiliki kualifikasi yang memadai. Pendidikan dan pelatihan merupakan proses yang harus dilalui untuk mengubah dan meningkatkan knowledge, skill dan attitude pesertanya sehingga memiliki kompetensi dan kualifikasi yang ditetapkan (Beer, Eisenstat, \& Spector, 1993; Garavan \& Barra, 1994). Institusi yang berwenang untuk membina dan menyelenggarakan pendidikan dan pelatihan ASN adalah Lembaga Administrasi Negara (LAN). Dalam perjalanan panjang untuk meningkatkan knowledge, skill dan attitude para CPNS, LAN telah berkali kali merubah model pembelajaranya dalam rangka wujud penyempurnaan pelaksanaan pendidikan dan pelatihan ini (Bastonus, 2020; Nugraha, 2019).

Program Latsar CPNS merupakan program pelatihan yang memerlukan evaluasi yang tujuannya untuk mengetahui keberhasilan pelaksanaan Latsar CPNS. Pencapaian tujuan penyelenggaraan Latsar CPNS memerlukan kemampuan memberdayakan sumbersumber daya yang tersedia secara efektif dan efisien, yang disertai dengan kemampuan memanfaatkan kekuatan dan peluang yang ada dengan meminimalisir kelemahan dan tantangan yang dihadapi. Penyelenggaraan Latsar CPNS berbasis pada kebutuhan peserta dan dilaksanakan secara profesional dan proporsional dengan memperhatikan dua hal pokok yaitu proses pelaksanaan Latsar CPNS dan penerapan pasca Latsar CPNS (LAN-RI, 2019).

Kompetensi yang dibangun dalam Latsar CPNS pola baru ini adalah kompetensi PNS sebagai pelayan masyarakat yang profesional, diindikasikan dengan kemampuan mengaktualisasikan lima nilai dasar yang sering disingkat dengan sebutan Nilai ANEKA yaitu: 1) akuntabilitas, yaitu kemampuan mewujudkan akuntabilitas dalam melaksanakan tugas jabatannya, 2) nasionalisme, yaitu kemampuan mengedepankan kepentingan nasional dalam pelaksanaan tugas jabatannya, 3) etika publik, yaitu menjunjung tinggi standar etika publik dalam pelaksanaan tugas jabatannya, 4) komitmen mutu, kemampuan berinovasi untuk peningkatan mutu pelaksanaan tugas jabatannya; 5) anti korupsi, kemampuan untuk tidak korupsi dan mendorong percepatan pemberantasan korupsi di lingkungan instansinya (Pemerintah Republik Indonesia, 2014).

Dengan pelaksanaan Latsar melalui pelaksaan ANEKA yang sudah dijabarkan, CPNS pola baru ini diharapkan mampu menanamkan nilai-nilai dasar profesi ASN tersebut dalam diri peserta Latsar CPNS sehingga dapat menghasilkan PNS yang profesional, yaitu ASN harus mampu menciptakan kutur baru di birokrasi dengan mandat pelayanan yang dimulai dengan kesadaran bela negara, membentuk karakter dan bersikap profesional dalam mengelola tantangan dan masalah keragaman sosiokultural dengan perspektif WoG yang didasari nilai kebangsaan berdasarkan peran dan kedudukan ASN dalam NKRI (Anoraga, 2018).

Sehingga setiap ASN harus dan wajib menjadikan setiap perbuatannya memiliki konsep pada nilai-nilai yang terkandung dalam ANEKA agar terwujud ASN yang profesional (LAN, 2016). Menjadi ASN bukanlah hal yang mudah, tapi bukan berarti tidak bisa menjadi PNS yang baik. ASN Abdi Negara Berkualitas, mewujudkan ASN era Industri 4.0 yang kredibel, profesional dan berdaya saing (Hariyanto, 2019).

\section{METODE}

Metode yang digunakan adalah Penelitian Campuran (Mix) yaitu kuantitatif dan kualitatif. Tahap kedua dilakukan analisis kuantitatif dengan menggunakan analisis sebelum dan sesudah (Before and after analysis) dengan menggunakan metode Paired Samples $t$ Test sehinggga tidak ditemukan besar/nilai pengaruh melainkan hanya membandingkan ada tidaknya pengaruh dan membandingkan pengaruh nilainilai dasar ANEKA terhadap perilaku berdasarkan jumlah responden yang menjawab (Mertens \& McLaughlin, 2004). Teknik pengumpulan data kuantitatif dengan cara Tes (pre test), perlakuan atau eksperimen semu, observasi dan tes (post test) (Trundle \& Bell, 2010). Kelompok eksperimen terlebih dahulu diberikan pretest Sebelum diberi perlakuan, kemudian diberi perlakuan (treatment) dengan memberikan pelatihan kepada peserta Pelatihan Dasar CPNS tentang nilai-nilai dasar ANEKA, setelah itu peserta tersebut yang telah diberikan pelatihan diberikan kesempatan untuk mengimplementasikan pembelajaran pelatihan tersebut pada tempat kerja masing-masing yang kemudian diberikan post test. Dalam pendekatan kualitatif dilakukan dengan metode analisis deskriptif kualitatif dengan menggunakan kuisioner terbuka dan wawancara berjangka, dengan aspek yang diteliti adalah perilaku kerja peserta pelatihan setelah mereka kembali ke dalam lingkungan kerjanya. Perilaku kerja yang di lihat dikaitkan dengan materi pelatihan yang diberikan.

Lokasi Penelitian pre test dilaksanakan pada Pusat Kajian dan Pendidikan dan Pelatihan Aparatur I LAN yang bertempat di Jatinangor, dalam pelaksanaan Latsar ASN Tahun 2019, sedangkan penelitian post test dilaksanakan pada tempat kerja masing-masing peserta Latsar ASN.

Populasi merupakan peserta Latsar CPNS Angkatan 1 sampai 12 Tahun 2019. Penyebaran kuesioner dilakukan secara daring (online). Dengan jumlah kuesioner 220 sampel Peserta Latsar CPNS dan 89 sampel untuk mentor peserta, Sedangkan dalam teknik pengumpulan data kualitatif dilakukan dengan 
kuesioner dan wawancara terbuka kepada peserta Latsar CPNS dan para pengelola SDM/Unit kerja peserta Latsar
CPNS sebagai responden, untuk lebih jelas dapat di lihat pada tabel 1 sebagai berikut:

Tabel 1. Deskripsi Responden Berdasarkan Asal Daerah/Lembaga

\begin{tabular}{llllc}
\hline \multicolumn{1}{c}{ Penelitian } & \multicolumn{2}{c}{ Karakteristik } & \multicolumn{1}{c}{ Asal Daerah/Lembaga } & Jumlah Responden \\
\hline Kuantitatif & Peserta Latsar & CPNS & Pemerintah Kabupaten Tasikmalaya & 106 orang \\
& Angkatan 1 s/d 12 & & BPOM, Kementerian Pariwisata dan & 56 orang \\
& & & Lembaga Penerbangan dan Antariksa & \\
& & & Nasional & \\
Kulitatif & Pejabat unit kerja & peserta & Pemerintah Kabupaten Tasikmalaya, & 8 orang \\
& Latsar CPNS & & BPOM, Kementerian Pariwisata dan & \\
& & Lembaga Penerbangan dan Antariksa & Jumlah & $\mathbf{1 7 0 ~ o r a n g}$ \\
& & Nasional & & \\
& & & &
\end{tabular}

Pedoman pengambilan keputusan dalam uji Paired Samples $t$ Test berdasarkan nilai signifikansi (Sig.) hasil out put SPSS (Blair \& Higgins, 1985; Roberson, Shema, Mundfrom, \& Holmes, 1995), adalah sebagai berikut :

1. Jika nilai Sig. (2-tailed) $<0,05$, maka H0 ditolak dan Ha diterima.

2. Jika nilai Sig. (2-tailed) $>0,05$, maka H0 diterima dan Ha ditolak.

\section{HASIL DAN PEMBAHASAN}

Selain dengan membandingkan antara nilai Signifikansi (Sig.) dengan probabilitas 0,05, untuk menguji hipotesis dapat dilakukan pula uji nilai $t$ dan membandingkannya dengan $t$ tabel. Adapun pedoman atau dasar pengambilan keputusannya adalah sebagai berikut :

1. Jika nilai t hitung $>\mathrm{t}$ tabel, maka $\mathrm{H} 0$ ditolak dan $\mathrm{Ha}$ diterima.

2. Jika nilai t hitung $<\mathrm{t}$ tabel, maka $\mathrm{H} 0$ diterima dan $\mathrm{Ha}$ ditolak.

Tabel 2. Hasil Pengujian Paired Samples t Test Pada Data Peserta Latsar CPNS

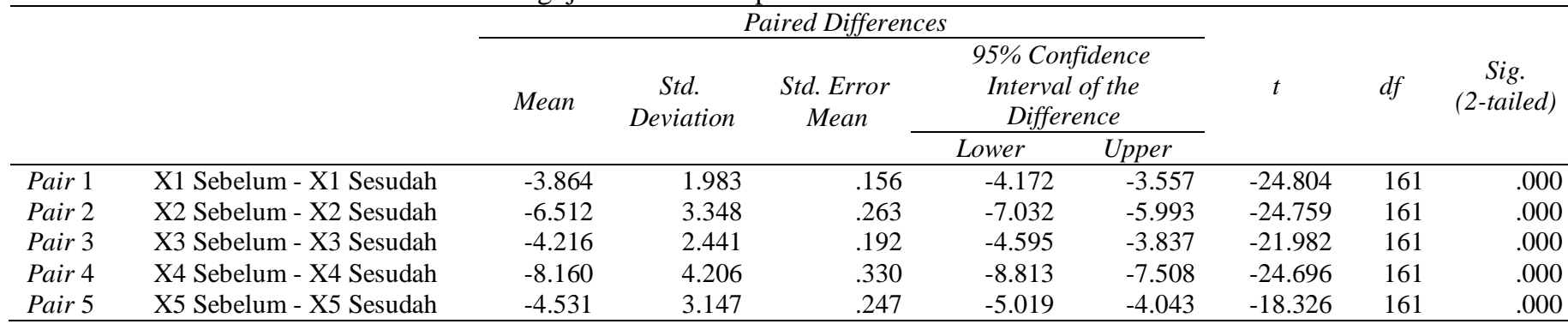

Berdasarkan tabel di atas, terlihat kolom Mean negatif, merupakan selisih antara rata-raat nilai sebelum dan sesudah dan seluruh nilainya berada diantara interval dengan tingkat kepercayaan $95 \%$ Confidence Interval of Difference Lower and Upper. seluruh nilai untuk masing masing nilai-nilai dasar Akuntabilitas (X1), Nasionalisme (X2), Etika Publik (X3), Komitmen Mutu (X4) dan Anti Korupsi (X5) memiliki t hitung yang bernilai negatif, $t$ hitung negatif disebabkan nilai ratarata seluruh nilai-nilai dasar Akuntabilitas (X1), Nasionalisme (X2), Etika Publik (X3), Komitmen Mutu (X4) dan Anti Korupsi (X5) yang sebelum pelatihan dasar lebih kecil dari rata-rata sesudah pelatihan dasar, untuk kasus ini maka bisa dikonversikan menjadi bernilai positif. Sehingga dapat disimpulkan bahwa ada perbedaan rata-rata antara hasil belajar sebelum dengan sesudah Latsar CPNS, yang artinya terdapat pengaruh nilai nilai dasar Akuntabilitas (X1), Nasionalisme (X2), Etika Publik (X3), Komitmen Mutu (X4) dan Anti Korupsi (X5) dalam meningkatkan perubahan perilaku peserta sebelum dan sesudah dalam mengikuti Latsar CPNS.

Dari hasil Analisis sebelum dan sesudah (Before and after analysis), dengan menggunakan uji beda rata rata terlihat ada atau tidaknya pengaruh setiap nilai ANEKA terhadap perilaku berdasarkan jumlah responden yang menjawab, bahwa semua peserta Latsar CPNS telah mengalami perubahan perilaku relatif menjadi baik setelah mengikuti pelatihan, dapat dijelaskan sebagai berikut:

1. Berdasarkan tabel dalam out put pair 1 tabel di atas, diperoleh nilai Sig. (2-tailed) sebesar 0,000 <0,05, maka dapat disimpulkan ada perbedaan rata-rata hasil belajar materi Akuntabilitas (X1) sebelum dengan sesudah mengikuti Latsar CPNS, yang artinya terdapat pengaruh mengikuti Latsar CPNS, bahwa peserta Latsar CPNS telah memahami nilai-nilai dasar dan konsep akuntabilitas dalam pelaksanaan tugas, bila terjadi konflik kepentingan, tetap mematuhi peraturan perundangan yang berlaku, 
memahami tugas dan pekerjaan yang menjadi tanggung jawabnya, berkinerja baik dan maksimal guna mendukung kinerja organisasi, menyadari untuk selalu memberikan layanan yang adil dan merata kepada pengguna jasa, senantiasa netral terhadap kepentingan-kepentingan pihak yang dilayani dan memahami nilai-nilai akuntabilitas dan aktualisasinya dalam tugas/pekerjaannya.

2. Berdasarkan tabel dalam out put pair 2, diperoleh nilai Sig. (2-tailed) sebesar 0,000 $<0,05$, maka dapat disimpulkan ada perbedaan rata-rata hasil belajar peserta Latsar CPNS sebelum dengan sesudah mengikuti Latsar CPNS, yang artinya terdapat pengaruh mengikuti Latsar CPNS dalam meningkatkan perilaku Nasionalisme (X2), bahwa peserta Latsar paham akan peranan Pancasila dalam menumbuhkan nasionalisme pada dirinya, paham akan peran sebagai pembuat dan pelaksana kebijakan publik, memahami dan menyadari perannya sebagai pelayan publik., paham dan sadar untuk selalu menjadi perekat dan pemersatu bangsa dan memahami serta menyadari untuk senantiasa mengimplementasikan nilai nilai Pancasila dalam setiap pelaksanaan tugas.

3. Berdasarkan tabel dalam out put pair 3, diperoleh nilai Sig. (2-tailed) sebesar $0,000<0,05$, maka dapat disimpulkan ada perbedaan rata-rata hasil belajar peserta Latsar CPNS sebelum dengan sesudah mengikuti Latsar CPNS, yang artinya terdapat pengaruh mengikuti Latsar CPNS dalam meningkatkan perilaku Etika Publik (X3), bahwa peserta Latsar CPNS Sebagai pegawai/pejabat publik paham terhadap kode etik yang harus dipedomaninya, mengetahui berbagai sikap dan perilaku yang bertentangan dengan kode etik, mengetahui dan menyadari implikasi/akibat yang diterimanya apabila melanggar kode etik dan norma yang berlaku dan senantiasa sadar untuk bersikap dan berperilaku sesuai dengan kode etik dan norma yang berlaku.

4. Berdasarkan tabel dalam out put pair 4, diperoleh nilai Sig. (2-tailed) sebesar $0,000<0,05$, maka dapat disimpulkan ada perbedaan rata-rata hasil belajar peserta Latsar CPNS sebelum dengan sesudah mengikuti Latsar CPNS, yang artinya terdapat pengaruh mengikuti Latsar CPNS dalam meningkatkan perilaku Komitmen Mutu (X4), bahwa peserta Latsar CPNS mampu mengidentifikasi dan mendeskripsikan fenomena empirik efektivitas dan efisiensi kinerjanya di tempat tugas, mampu mendeskripsikan karakteristik ideal dari tindakan yang efektif, efisien, inovatif, dan berorientasi mutu dalam melaksanakan tugas, mampu memberikan contoh nyata pemberian layanan publik yang efektif, efisien, inovatif, dan berorientasi mutu, paham akan konsekuensi penyelenggaraan kerja yang tidak efektif dan tidak efisien, mampu mengidentifikasi dan mendeskripsikan nilai-nilai dasar orientasi mutu, dapat mendeskripsikan implementasi pendekatan inovatif dalam penyelenggaraan tugas dan mampu menganalisis berbagai upaya untuk meningkatkan produktivitas kerja saya.

5. Berdasarkan tabel dalam out put pair 5, diperoleh nilai Sig. (2-tailed) sebesar 0,000 $<0,05$, maka dapat disimpulkan ada perbedaan rata-rata hasil belajar peserta Latsar CPNS sebelum dengan sesudah mengikuti Latsar CPNS, yang artinya terdapat pengaruh mengikuti Latsar CPNS dalam meningkatkan perilaku Anti Korupsi (X5), bahwa peserta Latsar CPNS mampu menjelaskan berbagai dampak dari perilaku dan tindak pidana korupsi, memahami pengertian korupsi yang dimaksudkan dalam peraturan perundangan, mampu mengenali delik-delik tindak pidana korupsi yang berlaku di Indonesia, memiliki niat, semangat, dan komitmen melakukan pemberantasan korupsi dan bertekad bulat untuk mewujudkan Indonesia yang bebas dari korupsi.

Berdasarkan gambaran dari hasil penelitian dari hasil jawaban wawancara terbuka terungkap beberapa hambatan bahwa peserta Latsar CPNS mendapatkan kesulitan untuk mengaktualisasikan nilai-nilai dasar ANEKA dalam bentuk perilaku kerja, hal ini berarti pemahaman nilai-nilai dasar ANEKA yang didapatkan dalam proses pembelajaran Latsar CPNS dengan nilai akademik yang sangat tinggi, pada saat praktek pengaktualisasinya tidak mudah dan diperlukan suatu cara (strategi) yang tepat disesuaikan dengan situasi dan kondisi yang dihadapi di lapangan (Hanson, 1996; Howard, 1977; Steers, 1981) bahwa perilaku merupakan hasil daripada segala macam pengalaman serta interaksi manusia dengan lingkunganya yang terwujud dalam bentuk pengetahuan, sikap dan tindakan (Hanson, 1996; Howard, 1977; Steers, 1981). Perilaku merupakan respon/reaksi seorang individu terhadap stimulus yang berasal dari luar maupun dari dalam dirinya (Glanz, Rimer, \& Viswanath, 2008). Kesulitan lain yang dihadapi adalah karena lingkungan kerjanya yang kurang mendukung (Budaya kerja, lingkungan kerja, dukungan rekan kerja dan adanya dukungan pejabat) untuk terjadinya perubahan perilaku (Hagger, Cameron, Hamilton, Hankonen, \& Lintunen, 2020) , faktor lingkungan ini sangat besar sekali pengaruhnya dalam menentukan perilaku, bahkan kekuatanya lebih besar daripada karakteristik individu (Klump, McGue, \& Iacono, 2002; Stern, 2000)

Sedangkan hasil penelitian kualitatif yang dilakukan dengan pejabat unit kerja pengelola instansi pengirim peserta Latsar CPNS yaitu Pemerintah Kabupaten Tasikmalaya, Badan Pengawas Obat dan Makanan, Kementerian Pariwisata dan Lembaga antariksa dan Penerbangan Nasional sesudah pembelajaran nilai-nilai ANEKA kepada peserta Latsar CPNS, didapat hasil bahwa para peserta telah melaksanakan kebijakan publik dengan baik, 
memberikan layanan publik dengan baik, berkomunikasi dengan bawahan, teman sejawat dan pejabat dengan baik. memotivasi bawahan dan teman sejawat, melaksanakan kedisiplinan (kehadiran tepat waktu, berpakaian sesuai ketentuan, ketepatan dan kecepatan menyelesaikan tugas, bertanggung jawag terhadap tugas yang dibebankan, bertanggung jawab terhadap alokasi anggaran, bekerja dengan profesional (tepat, cepat namun tetap cermat dan teliti), bekerja dengan mengedepankan kepentingan publik di atas kepentingan pribadi, membuat ide yang kreatif dan inovatif untuk kemajuan organisasi, pengelola SDM/Unit kerja masing masing merasakan manfaat yang sangat besar atas perubahan perilaku para peserta yang telah mengikuti Latsar CPNS. Mereka berkesimpulan terjadi perubahan perilaku para peserta secara signifikan sesuai dengan perilaku yang diharapkan sebagai seorang CPNS profesional dibandingkan dengan sebelum diikutsertakan pada Latsar CPNS.

\section{SIMPULAN}

Berdasarkan hasil analisis yang telah dilakukan, dapat ditarik kesimpulan bahwa:

1. Program Latsar CPNS sesuai dengan harapan peserta sehingga dapat merubah perilaku para peserta Latsar CPNS khususnya mengenai nilai nilai dasar ANEKA.

2. Pembelajaran ANEKA akan berpengaruh positif terhadap perilaku peserta Latsar CPNS. Pembelajaran nilai nilai ANEKA yang paling tinggi pengaruhnya adalah pada nilai nilai dasar komiten mutu (X4) dan yang paling rendah adalah nilai nilai dasar Akuntabilitas (X1).

3. Peserta Latsar CPNS sudah melaksanakan nilai nilai aneka dalam bentuk perilaku kerja, namun mendapatkan kendala/kesulitan mengaktualisasikan nilai-nilai dasar ANEKA dalam bentuk perilaku kerja, beberapa faktor hambatan menimbulkan kesulitan dalam implementasi ANEKA yaitu:

a. Kesulitan mengaktualisasikan ANEKA dalam bentuk perilaku kerja (diperlukan strategi).

b. Kesulitan karena lingkungan kerjanya yang kurang mendukung.

c. Peserta Latsar CPNS masih kurang keinginannya untuk berubah (motif).

d. Peserta Latsar CPNS, saat mengaktualisasikan nilai dasar ANEKA kurang mendapatkan penghargaan.

4. Pengelola SDM/Unit kerja masing masing merasakan manfaat yang sangat besar atas perubahan perilaku para peserta yang telah mengikuti Latsar CPNS.

\section{DAFTAR PUSTAKA}

Anoraga, A. (2018). Nilai "Aneka" Mewujudkan ASN Berkualitas. Retrieved September 27, 2020, from https://www.kompasiana.com/abisekaa/5aeeb6f4f 1334404a06e7bc4/nilai-aneka-mewujudkan-asnberkualitas?page $=$ all
Bastonus, A. S. (2020). Proyek Perubahan dan Pemanfaatannya pada Pasca Pelatihan Kepemimpinan Tingkat Empat (4). Jurnal Agri Widya.

Beer, M., Eisenstat, R. A., \& Spector, B. (1993). Why change programs don't produce change. Managing Change, 2.

Blair, R. C., \& Higgins, J. J. (1985). Comparison of the power of the paired samples $t$ test to that of Wilcoxon's signed-ranks test under various population shapes. Psychological Bulletin, 97(1), 119.

Garavan, T. N., \& Barra, O. (1994). Entrepreneurship education and training programmes. Journal of European Industrial Training.

Glanz, K., Rimer, B. K., \& Viswanath, K. (2008). Health behavior and health education: theory, research, and practice. John Wiley \& Sons.

Grindle, M. S. (2007). Going local: decentralization, democratization, and the promise of good governance. Princeton University Press.

Hagger, M. S., Cameron, L. D., Hamilton, K., Hankonen, N., \& Lintunen, T. (2020). The handbook of behavior change. Cambridge University Press.

Hanson, E. M. (1996). Educational administration and organizational behavior. ERIC.

Hariyanto, E. (2019). Komunikasi Publik di Era Industri 4.0: Memetik Pelajaran dari Strategi Komunikasi Utang Pemerintah. @ jualinbukumu.

Howard, J. A. (1977). Consumer behavior: Application of theory (Vol. 325). McGraw-Hill New York.

Klump, K. L., McGue, M., \& Iacono, W. G. (2002). Genetic relationships between personality and eating attitudes and behaviors. Journal of Abnormal Psychology, 111(2), 380.

LAN-RI. (2019). Pelatihan Dasar CPNS - Pusbangpeg ASN. Retrieved September 29, 2020, from https://pusbangasn.bkn.go.id/tag/pelatihan-dasarcpns/

LAN. (2016). Modul Pendidikan dan Pelatihan Dasar Calon PNS (Habituasi). In Lembaga Administrasi Negara.

Mertens, D. M., \& McLaughlin, J. A. (2004). Quantitative research methods: Questions of impact. Research and Evaluation Methods in Special Education, 51-68.

Mutia Ali, D., Prasojo, E., \& Jannah, L. M. (2017). The Transformation of Merit System in Indonesian Civil Servant Promotion System. International Journal of Management and Administrative Sciences (IJMAS, 5(04), 20-28. Retrieved from www.ijmas.orgwww.ijmas.org

Nugraha, H. (2019). Model Implementasi Inovasi di Sektor Publik Studi pada Inovasi E-Office Satu Pintu di Puslatbang PKASN LAN Innovation Model in The Public Sector Innovation Case 
Study of One-Stop E-Office at Puslatbang PKASN LAN. Jurnal Wacana Kinerja.

Pemerintah Republik Indonesia. Undang-Undang Nomor 5 Tahun 2014 Tentang Aparatur Sipil Negara., (2014).

Riccucci, N. M., Naff, K. C., \& Hamidullah, M. F. (2019). Personnel management in government: Politics and process. Routledge.

Roberson, P. K., Shema, S. J., Mundfrom, D. J., \& Holmes, T. M. (1995). Analysis of paired Likert data: how to evaluate change and preference questions. Family Medicine, 27(10), 671-675.

Steers, R. M. (1981). Introduction to organizational behavior. Goodyear Publishing Company.

Stern, P. C. (2000). New environmental theories: toward a coherent theory of environmentally significant behavior. Journal of Social Issues, 56(3), 407424.

Trundle, K. C., \& Bell, R. L. (2010). The use of a computer simulation to promote conceptual change: A quasi-experimental study. Computers \& Education, 54(4), 1078-1088. 